Commentary

Open Access

Eugene Steuerle*

\title{
Will the Nonprofit Sector Strengthen Itself? Or Merely Engage in Defensive Efforts?
}

DOI 10.1515/npf-2016-0033

Abstract: In the post-2016 election period, nonprofit institutions, particularly charities, might react to new challenges in more than a defensive way. Opportunities include much greater self-examination of ways to enhance the effectiveness of their own actions and making trade-offs in the forthcoming tax and spending debates that stress exchanging less effective provisions for more effective ones.

Keywords: charity, tax, election

The past election period, even before its conclusion, certainly shook up many people and institutions. While charities and the broader nonprofit sector represent only one segment of society, with charitable contributions at 2 percent of personal income and nonprofit sector employment at 9 or 10 percent of the labor force, [https://rowman.com/ISBN/9781442271777/Nonprofits-and-GovernmentCollaboration-and-Conflict-Third-Edition], they play a powerful role in defining and challenging the energies and beliefs of almost all segments of our society.

In considering implications for the sector, my thoughts are necessarily speculative but fall into two categories. First, whatever their politics, to what extent will charities engage the requirements of the time, attempt to decipher the lessons it offers, and seek new and different opportunities? Second, how might they consider their response to the likely policy debates, such as impact of tax changes on charitable giving? In both cases, I suggest approaches and actions beyond mere defensive reactions to the new pressures on the sector. In posing questions that I think the sector needs more fully to engage, I do not presume to know the answers.

\section{The New Opportunities, Wanted or Not}

The past campaign season revealed a number weaknesses in our democratic institutions. The challenge to fact-based debate has never been higher, but let's

*Corresponding author: Eugene Steuerle, Urban Institute, 2100 M St., NW, Washington, DC 20037, USA, E-mail: Steuerle@comcast.net 
not delude ourselves that we haven't defined deviancy down for long time. Nonprofit and news institutions that engaged in modest levels of fact checking have always had a hard time competing against interest groups, several of which are in the nonprofit but not necessarily charitable part of the sector, and some of which individually spend tens of millions of dollars providing selective and often misleading information to support their causes. Yes, there was a growth in news and social outlets that spread falsehoods, myths and half-truths, but it's long been true that commercial news outlets thrive on controversy in ways that promote it. It shouldn't be surprising in this media world that each party's nominees were both more famous than other candidates for their party's nomination, and that controversy itself added to their fame.

If truth and reasonable debate is to gain traction, will actors in the nonprofit sector work to strengthen democratic institutions, and how? Will they do more than provide very limited support to fact checking organizations? Will they examine their own ways of disseminating information, whether directly or through the organizations they support?

How will grant-making foundations react? Many are known for their liberal or conservative orientation, which is fine when they seek to emphasize some legitimate liberal or conservative principle, such as progressivity or efficiency, rights of equal justice or property. But many also support advocacy groups that identify with political party stances often inconsistent with those principles and, as advocates, fail to acknowledge other principles deserving of consideration. For instance, how can one favor or oppose some spending or tax program without relating that support to its size, who might pay, who is left out? In a world of identity politics, the election also gave warnings about neglecting those who feel left out, whether by different measures they are or not.

I've had the privilege over the years of working with admirable nonprofit leaders who attempt to represent fairly large segments of the sector, but their members often press them mainly to protect and defend some status quo rather than strengthen the sector from within. In my own area of expertise, these affirmative efforts could include: fostering greater self-policing in areas of abuse, such as overstated valuation of in-kind charitable deductions; reducing the misappropriation of charities' names and brands for private purposes; and promoting greater ability internally to measure performance and self-criticize.

\section{The Upcoming Policy Debates}

New policy debates will soon arise and potentially engulf representatives of the nonprofit sector in protective efforts. However legitimate, I fear that a mere 
defensive stance by itself can make the sector appear to be just one more interest group, leading to further "them" against "us" style debates, and limited progress.

Many tax reform proposals from both Democrats and Republicans, including those from President Obama and President-elect Trump, would significantly restrict itemized deductions. Often these proposals have a disproportionate impact on the charitable sector, partly because charitable deductions are more highly concentrated among higher income individuals who would face the restrictions than are deductions for home mortgages or property tax.

But representatives of the sector need to be careful not to overstate their case against tax changes. The level of tax rate, for instance, does affect incentives to give, but taxes are raised mainly to pay for government. Therefore, those representatives cannot argue for rate increases or against rate reductions simply on the basis of the impact on the sector. Even with respect to the debate over whether a charitable deduction should be extended to all taxpayers, they must address legitimate concerns over the inability of IRS to monitor millions of returns claiming minor deductions.

In testimony [http://www.taxpolicycenter.org/sites/default/files/alfresco/publi cation-pdfs/901555-Tax-Reform-and-Charitable-Contributions.PDF] and elsewhere, I have suggested a way through these debates: that tax reform should aim to enhance charitable giving, while improving compliance and the share of deductions that truly are charitable. The trick is to exchange less efficient for more efficient incentives and provisions. Combinations include: a deduction for all taxpayers, not just itemizers, but only for giving above some floor level [http:// www.taxpolicycenter.org/sites/default/files/alfresco/publication-pdfs/the-newebate-over-a-charitable-deduction-for-nonitemizers.pdf]; allowing taxpayers to make contributions for one year up until the time of filing the following year [http://www.urban.org/sites/default/files/alfresco/publication-pdfs/412769Extending-the-Charitable-Deduction-Deadline-to-Tax-Day.PDF]; and placing restrictions on giving where cheating is likely to be quite significant.

Such compromises are often hard to negotiate one provision at a time. One stance the sector might take would be simply to ask legislators to insure that whatever direction tax reform may take, it be done in a way that would enhance or at least not restrict total giving, as estimated by the Joint Committee on Taxation or the Congressional Budget Office.

On the spending side of the budget, charities again will be engaged in many debates to help protect the persons they serve. Without going into detail here, I again suggest that they give some consideration to ways that part of the budget can be better allocated, not just on protecting each particular provision from which they draw support. For instance, if one wants to promote better 
educational opportunity, then one should also recognize the extraordinary extent to which direct supports for individuals in areas like healthcare are crimping education along with the rest of the budget.

\section{Conclusion}

In some areas charities and other nonprofit institutions have little choice but to take firm stances. Basic human rights must be protected and enhanced. People of all nations and colors and abilities must be treated with respect. Political contributions must never be allowed legally to qualify as charitable contributions without substantially corrupting the nonprofit sector.

At the same time, I have presented selected examples of how nonprofit institutions, particularly charities, might react to new challenges in more than a defensive way. Opportunities include much greater self-examination of ways to enhance the effectiveness of their own actions and making trade-offs in the forthcoming tax and spending debates that stress exchanging less effective provisions for more effective ones. 